\title{
Pathways out of Patronage Politics: New Roles for Communities, New Rules for Politics in the Philippines
}

\author{
Jude Esguerra III and Enrique Villanueva
}

\begin{abstract}
This case study discusses adaptations of co-production and co-financing approaches pioneered by two non-governmental organisations (NGOs) in the province of Palawan in Metro Manila, part of the Baranggay-Bayan Governance Consortium, a loose network of NGOs across the Philippines. The Consortium associates itself with local government officials, social movements and political parties that are interested not only in making use of the existing so-called democratic spaces but also of the political empowerment of the poor. It does so by creating community capabilities for increased bargaining power vis-à-vis local elected officials, reversing the exclusionary logic of patronage politics in the country and supporting co-production and co-financing between local governments and communities willing to put efforts towards solving their own problems.
\end{abstract}

\section{Introduction}

Service provision in the Philippines is wrapped within the logic of patronage politics. This means that when communities knock at the Mayor's door they may be able to secure the public goods they need, but in exchange for electoral support. When politicians promise to provide for a community's needs, their objectives typically involve creating relations of political patronage between themselves and community leaders. This kind of relationship has sustained the hold of clans over local politics. The same strategy of creating relations of dependence binds local politicians to national politicians and to Congressional district representatives who have access to finance from the capital in Manila.

This is the ecology within which the Institute for Popular Democracy (IPD) has been evolving its approach to local governance work in cooperation with the Baranggay-Bayan Governance Consortium (BBGC). ${ }^{1}$ When the Decentralization Law was passed in 1991, five years after the Marcos dictatorship collapsed, the IPD together with 30 members of the BBGC consortium of NGOs working on local governance, sought to find out how to make full use of the many openings for participation provided by the new law. Unfortunately, the demise of the dictatorship merely signalled the restoration of the pre-Martial Law elite dominance of national and local politics. A handful of exemplary leaders did emerge and continue to bubble up to prominence once in a while, but the effect of the handing over of more resources and regulatory powers to local governments has also been that of giving once moribund, political clans a second chance. There was a great mismatch between the powers of politicians and those of the movements and the fledgling political parties that sought to represent the marginalised groups (Quimpo 2008). 'Claim-making', as the attempt to use the language of rights and the openings in the decentralisation law is often called, often either fell on deaf ears, or merely allowed established politicians and their national patrons to strengthen the relations of dependence that are so much part of success in Philippine politics.

\subsection{Co-production and co-financing conceived as a political project} The IPD-BBGC initiative seeks to bring together various reform initiatives to make local 
governance responsive, participatory, and accountable, by:

- Supporting the specification and legitimation of new rules in the financing and provision of social services.

- Supporting local communities in their efforts to break free from the rules of patronage politics, and to make their priorities bankable in their own right.

- Generating knowledge about new mechanisms of citizens' self-help, cooperation and solidarity to support their co-production and co-financing of services.

- Supporting reform-oriented politics that aim to create non-traditional and democratic paths to power based on performance and responsiveness.

- Supporting actual on-the-ground demonstrations of how particular municipal services can be well delivered; how new rules and roles in the co-production and cofinancing of social services are documented, tested, and learned across networks of good governance champions; and how reformers in national agencies are recruited to push at the boundaries of what is possible.

There is a strong tradition of communities coming together to address urgent and common needs: for example, barriers of soil, stones and sticks may be constructed to conserve river banks as summer approaches, or obstructions may be moved to open a road that disappeared after a storm. Coming together to act on common problems in this way is called bayanihan, a practice that continues, particularly within and among communities that have had a significant history of working to build settlements together. The co-financing and coproduction methodology developed by the

IPD-BBGC sought a meeting point between what communities can do for themselves on the one hand, and what potentially progressive local politicians require in order to survive in politics, on the other (see Hickey and Mohan 2004). The general approach developed is extremely straightforward: it required that the community should first identify community projects that were important to them, as proven by their willingness to contribute to these. They would then approach the Mayor, the congressional representative or the governor to request that they shape local government priorities around those initiatives, that communities themselves are already willing to support. We look now at experiences with this approach to co-production of public services, with a focus on the political responses to such initiatives.

\section{Experiences with co-production and co-financing}

\subsection{When participation makes sense to politicians: the experience of Roxas, Palawan}

What incentives do politicians have to respond to community requests to align local government priorities with community priorities? In Roxas, Palawan province, Mayor Sabando accepted this new approach to community participation because it made considerable political sense. Local polls leading up to the 2004 elections placed Sabando a distant second (Lo 2003).

At the time, BBGC consortium partners were conducting participatory development planning exercises in some 2,000 baranggays across the Philippines. In Roxas, Palawan, this was being led by the Institute of Politics and Governance, in this case, to gain access to grants being made available by an international NGO. Seeing the enthusiasm of the communities for being involved in planning for the first time, Sabando made a promise that if he was re-elected he would consider the community planning exercise to be the start of a municipal-wide planning exercise. Projects that were not chosen by the community would not be funded under the municipal budget: community consensus about priority projects would be necessary. It is likely to have helped that in this instance the Mayor was in urgent search of a new political strategy that would allow him to catch up with his opponent. As he moved from one community to another to deliver his speech to open the participatory planning process, he became more and more committed. In the event, Sabando won a second term as Mayor of Roxas, by a margin considerably larger than his first victory. He also went on to win in 2007.

The community co-financing and co-production programme emerged as a pragmatic response to the constraints of local government development financing. The list of priority projects that communities selected in 2004 was too extensive to be funded by the municipality, even over a tenyear period. The municipal planning officer was anxious, for even if the local government devoted its entire budget to financing this list of projects, 
there would still be a lot of disappointment. Had opening up the budget and planning process created expectations that were impossible to fulfil?

The Institute for Popular Democracy and the Institute for Politics and Governance engaged in discussions with the Mayor and local government planning staff. During these discussions, bayanihan culture was invoked. One outcome was that the Mayor reiterated his commitment to devote the municipality's entire available budget to funding community priorities. However, he also asked the communities to identify projects that they were willing to co-finance with their labour, donations of materials, and with the small amount of budget that was available at the baranggay level for that fiscal year.

As a result, those projects deemed most urgent by the community became more visible as priorities among the others on the lists, revealed by the willingness of communities to dedicate their own resources to complement what the Mayor could offer. From thereon, the municipal planning staff were constantly in the communities, exploring how the municipality could shape its own expenditures around the resources that communities had dedicated for their priority projects. The acceptability of this approach was probably bolstered by the notion communicated during meetings with community leaders that this was simply a case of the local government helping those communities that were committed to helping themselves.

A particularly interesting aspect of the Roxas experience was how local political action succeeded in attracting political - and financial support at the national level. Mayor Sabando was a long-term political ally of the representative to congress for the area. Sabando was able to persuade the congressman to follow his lead, and to channel national-level resources to the municipality via this programme of communitylocal government co-financing. It helped that the congressman was a wealthy man, and politically secure in his position as the representative of the district to the National Congress. In Roxas, the project that the congressman supported is the project that the Mayor and the baranggay captain supported, following the lead of the community. In subsequent years, this model created an equilibrium of sorts for the Mayor, who no longer had to work on building patronage relationships; he merely needed to keep the promise he made in 2004 .

The circumstances in Roxas were not extraordinary. It is always possible to find communities willing to co-finance projects that they consider to be priorities. This willingness tends to be most evident in communities far from the centre of national politics, and which lack strategic importance in the formation of the political alliances required to consolidate election vote-banks. It is equally the case that it is always possible to identify congressional representatives who are politically secure, and who have no urgent need to make money out of contracts, and who are allies of local political leaders such as the Mayor. In other words, without making claims of general applicability, the co-production and co-financing approach has the potential to provide an alternative to patronage politics, an alternative that features greater participation, accountability and responsiveness to popular preferences.

\subsection{The limits of patron-based political support for community participation: the experience of Alimodian, Iloilo}

While circumstances such as those found in

Roxas are by no means unique, such participatory, community-driven approaches to public goods provision go against the political grain. The institutions and practices of Philippine politics have not evolved with the community at the centre, but in support of local and national elite strategies for reproducing their rule. Efforts to replicate the Roxas experience in other towns of Palawan province and elsewhere had met with varying degrees of success, demonstrating that this can fail as often as it can succeed.

For example, similar efforts in Alimodian in Iloilo province faltered after an initial period of success. The key factor was rivalry between the Mayor and the congressional district representative. When the Mayor chose to implement a more cost-effective approach to the implementation of public works, the congressional representative's public works firm lost business. This involved the routine mobilisation of community labour to tackle rural road bottlenecks in upland communities, also involving municipal engineering staff to supervise implementation (Lo 2003). 
In the case of Alimodian, there were no obvious contradictions between the economic, political and electoral objectives of the politician (the Mayor) and a participatory approach to local government. The Mayor recognised the financial constraints facing the town. She presented this problem to the baranggay captains, asking them to prioritise between road repairs, electricity connections, and new water systems.

The logic of co-financing was particularly compelling in this context because the Congressman withdrew all support for Alimodian, and devoted the Congressional funds that he was entitled to allocate to the other towns covered by his congressional district. By the time the case of the arterial road connecting all the baranggays was taken up, the baranggays had already exhausted the financing to which they had access on other projects. The Mayor and the baranggay captains reached an agreement to jointly take out a large loan, to be repaid over ten years. The cost-share of the towns was negotiated and towns that were farther away and would benefit more from the road rehabilitation agreed to pay more.

At this stage, the principle of community cofinancing was undermined and patronage politics was reasserted. The congressional representative destabilised the political bargain underpinning the co-finance proposal by telling baranggay captains that they did not need to draw on the limited resources of their communities to finance the road-building programme. Instead, if they agreed to support a candidate to challenge the incumbent Mayor in forthcoming elections, the Congressman promised to secure the resources from the Department of Public Works and Highways, to which his national political position gave him better access.

\subsection{Reforming national-local rules}

The politics of experiences with co-financing in Roxas and Alimodian highlight the many enabling conditions for the sustenance of routine patron-client relations within Philippine politics. Patronage politics clearly undermine the stability of bargains that enable community participation in local governance. With political incentives set up as they currently are, there are no guarantees that the Roxas experience with community co-financing will endure once a new Mayor or congressional district representative takes office. On the other hand, the situation in Alimodian may have been very different if the town had been receiving national government grants based on performance in public service provision. In both contexts, and indeed elsewhere, the local of political patronage would be undermined if congressional representatives had less control over central government funds and instead concerned themselves with their own mandates, including the development of legislation.

One of the many enabling conditions for the patron-client character of normal politics in the Philippines is the ability of the executive branch of government to secure the authority from congress to distribute lump sum funds based on vague rules that permit considerable scope for the exercise of political discretion. This is complemented by confidence among politicians of their capacity to periodically secure portions of these funds, and to receive public credit for doing so.

In such circumstances, NGO advocacy in relation to grant-making legislation takes on considerable significance. Within discussions on lump sum grants, both in favour and against, there are other approaches that may point a way forward. One is the cost-sharing policy guidelines formulated by the Cabinet-level Investment Coordination Committee of the National Economic and Development Authority. These guidelines set out the purpose of the grant, and the proportion of financial help to be extended for each type of project. The cost-sharing policy is designed to augment local government resources, encouraging financing of projects that would otherwise not be prioritised, but which rank high among national government priorities. The cost-sharing policy allows for equity in relation to local government income levels and potential cost recovery, so that bus terminals or public markets receive less funds than projects with low potential for cost recovery, such as municipal roads. Projects with a low visibility impact such as irrigation should receive more funds than those with a high visibility impact, such as roads. Projects with high positive externalities across different local government units (e.g. watershed management projects) are entitled to more funds than those with fewer positive spillover effects. 
In contrast to lump sum grants, funds released through cost-sharing policies are essentially performance-based grants. These are open to all local government units at certain minimum requirements (e.g. classified as low income). Crucially, grants are released on the basis of performance or selection of projects that are aligned with national government priorities. Since cost-sharing policy funds are based on rules and performance metrics, this type of grant is more transparent, and therefore less prone to corruption or to being used to support patronage politics. At the same time, performance-based grants reward local government units that invest in projects that are needed by the public, but may be politically less attractive.

While it may prove difficult and politically infeasible to expect the national executive to abruptly relinquish discretionary powers over lump sum funds, some kind of transition towards a cost-sharing policy has been signalled for the future, particularly in relation to local government units that are resource-poor and lack political strategic importance. Other possibilities are being discussed in relationship to the financing of local health programmes and, as discussed below, with respect to water services.

\subsection{The power of collective action on water}

In Caloocan city, a far wealthier municipality than Roxas, the organisations of the urban poor do not hope to transform the patronage-basis of governance overnight. But in part of it, Bagong Silang, the biggest baranggay in the country, they do want the city government to respond to their decades-old frustration of only having piped supply of water for one-third of the 400,000 population. Currently, water supplies are so expensive, at around five times the cost of piped water, and delivered supplies so unpredictable, that people typically consume only 40 litres per person per day, in contrast to the 93 litres of piped water consumed on average by poor people in Metro Manila.

The incentives for local political actors to act to deliver piped water to all in Bagong Silang appear unpromising. The Mayor has a well-oiled electoral machine that has already delivered success in the 2004 and 2007 elections, and is likely to do so again in 2010 . He has little direct motivation to re-cast his relationship with the communities as Mayor Sabando in Roxas did for political survival. In terms of day-to-day politics, in every corner of the giant baranggay are community leaders who are loyal to the Mayor. These leaders actively mediate on behalf of their communities to lend credibility to the notion that the good Mayor is delivering enough of the expressed needs of people who have petitioned him for aid; to date this has proven to be enough to prevent those who had supported the Mayor in 2007 from shifting their allegiance to the two other candidates who are expected to stage a challenge in 2010.

Bagong Silang is not yet a success story around the co-financing and co-production of public services. But with some support from the Institute for Popular Democracy, the community of Maharlika is beginning to show the rest of the baranggay how it might be possible to take incremental steps that could alter the rules of who gets what, when and how. In doing so, Maharlika is becoming a learning laboratory for the rest of the BBGC, as the situation being faced by Maharlika is relevant for the rest of the country, where it is typically only the centre of town that is supplied with piped water by the Water District, with the rest forced to buy expensive supplies from truckers, draw water from hand pumps or buy bottled water.

In Maharlika, action on water began when around 20 community leaders decided it was better to act than to wait, and formed a water service cooperative by raising capital from among their members. They believed that once the other community members could see the water flowing in some parts of Maharlika, they would also join in the cooperative and supply capital. This hunch was inspired by the experience of nearby Taguig city, where water had been piped to an informal settlement of the urban poor through community financing, under conditions when neither the city nor the private water concessionaire had the capital or the incentives to do so. The plan developed jointly by the Maharlika cooperative and the IPD was for the cooperative to develop a business plan for extending the reach of the privatised partners of the Metro Manila Waterworks and Sewerage System beyond the boundaries of commercial viability. This was to be done initially for Maharlika and then for other parts of this giant baranggay. The plan was: 
- To convince more local community members to join the cooperative, so that on the strength of that equity and the business plan, they could raise funds from creditors.

- To persuade the local government to provide performance-based grants to communities that managed to set up water cooperatives. The city would pay half of the capital expenditures incurred if the cooperative was achieving its targets for increased water service coverage, hours of availability, quality and affordability within a year.

- To persuade the private operator of the Metro Manila Waterworks and Sewerage System to give significant discounts per cubic metre in order to compensate community water cooperatives for some of the business risks and the operational costs that they would be taking, including investing in the infrastructure.

These ideas emerged from theoretical perspectives on co-production and arguments developed in discussion both within the community and within the IPD. The community believed that they could perform better than either a private provider or a public bureaucracy in the delivery of 'last mile water services'. They recognised that community-based water service providers had the eyes, the ears and the microlevel political sense needed to monitor and address water theft and leaks that the private operator had been unable to address in the ten years since privatisation. They also knew that the old way of doing things could not be made to work on their side of Metro Manila, with some 60 per cent of the clean water that leaves the Metro Manila Waterworks and Sewerage System plant being lost to leaks and theft, and failing to generate an income for the company. It did not help that the company, perhaps at the urging of its creditors, reduced the number of field personnel in 2007.

The community also believed that they were better motivated than these actors because they and their families would suffer directly if the leaks and theft were not addressed, and that this would lead to water quality deterioration and to higher costs. There was also no risk of overpricing, which had happened in Taguig, because the cooperative would regulate itself and not others; the members who governed the cooperative would want to keep rates affordable, as they themselves were to pay these rates.
At the political level, the working hypothesis was that there was nothing to be lost and everything to be gained, providing the Mayor and the local legislature provided a minimum of support and agreed to create the space in which to experiment. There were, however, concerns, as the rumour was that the Mayor had a lucrative income from the water trucks (prominently bearing his name and photograph) that made twice-weekly deliveries to the communities without piped water. Although there was no hard evidence of such gains, the water trucks were popularly called 'RafRaf', after a former Mayor's son who took on water trucking as a business while his father was in city hall, underlining the powerful political interests at stake in preventing the establishment of an efficient system of piped water. However, discussions between the cooperative members and the IPD concluded that if it could be demonstrated that performance-based grants from the city government could induce water cooperatives to help themselves, there would - at least at the city level - be nothing to be lost and everything to be gained by replacing the expensive and intermittent delivery of water through trucks with the more efficient delivery through pipes.

It is never easy for communities to pool their resources for collective action, even when they know that this is what is needed to change the rules of engagement with government. But the theory is that the barriers to raising capital can be low in instances where the aim is simply to shift from individualised and expensive modes of service access, towards modes which are collective, cheaper and offer greater access. The view of the IPD is that sooner or later creditors, and even angel investors, would enter into the picture, as a result of the considerable potential for financial viability. For even without discounts from the wholesale purchase of water, the cooperative was likely to break-even, even when taking into account the cost of reducing the price of water by half.

After one year, this community initiative in Bagong Silang had already reached 120 of the 400 households it has targeted to reach within three years. It failed to secure loan financing as planned but, as in Taguig city, made investments on an incremental basis, based on the gradual accumulation of membership share capital, high interest loans from friends of the cooperative 
and net monthly earnings. By taking on the organisational form and the internal financial controls of a cooperative, it avoided some of the pitfalls of the Taguig city experience, where rumours were that community leaders had enriched themselves, earning the political hostility of elected officials who were not invited to play a role in the community initiative.

A year after the Maharlika cooperative experiment began, three other communities in Baranggay Bagong Silang are already planning to imitate the collective action effort of Maharlika. In Davao, Bacolod and Iloilo cities there are other communities that will probably broadly follow the strategy adopted in Bagong Silang. Like Bagong Silang, these are 'waterless communities' whose water needs place them beyond the realm of commercial viability as conventionally assessed. These communities intend to call on local governments to meet their mandates for water provision as set out in the 1991 Decentralization Law. They also aim to explore pathways out of the patronage system that has kept them dependent and waiting for the delivery of essential needs such as water. In its turn the Baranggay-Bayan Governance Consortium on NGOs will be working with these different initiatives to discover how to pursue theory building from the ground up, based on successes and failures in these new areas. Is there a collective action dynamic characteristic of the delivery of water or other services across localities or even countries with different legal frameworks? The challenge for the consortium members is now that of enabling effective organisational learning effort through conversations across and between these poor urban communities.

\subsection{Re-visiting and revising assumptions in Bagong Silang: learning through action}

One year on from the Maharlika experiment with collective action to provide piped water, the working hypotheses that guided the initial strategy seems rather optimistic and lacking in some key nuances. The Metro Manila

Waterworks and Sewerage System and its private partner are still reluctant to offer discounts for the wholesale purchase of water, possibly because of the fear that this would in fact increase the viability of water service cooperatives, creating a vociferous new sub-sector to whom they would need to be accountable. Upon request of the private water supply partner of the Metro Manila Waterworks and Sewerage System, the IPD drafted detailed terms of reference containing assurances and concessions necessary for the cooperative to reduce its business risks. These included granting the cooperative exclusive rights to service provision in its area, instalment plans for mother meters and main pipes that extend to the community, and a gradual upgrading of construction standards; however, none of this was formalised in writing. Other conditions, such as charging service lines and mother meters to the balance sheet of the company, and the provision of wholesale discounts on water supplies were not granted. There has been no subsequent meeting since then, and the local manager of the private water company was instructed by their central office to stop discussions with the IPD.

The water services cooperative in Maharlika developed a business plan with standard specifications and supporting schedules, with which it approached a prospective lender. But the lender appeared unable to assess the risks and returns of a collateral-free loan in the case of water initiatives with no track record in project execution. The lender offered a small grant instead. One lesson has been that a programme of partial guarantees would have been useful to induce lenders to learn about the bankability of community initiatives such as the Maharlika water services cooperative. The early arrival of equity contributions could also have made a significant difference to the pace of implementation. But as the IPD discovered, people in Bagong Silang have had previous experiences of organisations being set up for collective purposes, only for their contributions to be embezzled. In the Maharlika experience, households were only inclined to contribute capital when the secondary pipes were actually in front of their houses; such is the mode of risk mitigation that their experience has taught them.

After many attempts, the Mayor has yet to find time to meet the group. But his son, the president of Caloocan city's Association of Baranggay Captains (himself a local legislator) invited the Institute for Popular Democracy and the Maharlika water service cooperative's officers to discuss the issue. He declared that he liked the draft local legislation for performancebased grants that the group had developed, and 
claimed to have presented it to other baranggay captains as his own draft legislation. The draft law has, however, yet to make progress within the local legislature. Instead, the Mayor's son donated some pipes to the cooperative, which, while useful, has not satisfied the cooperative's officers. They plan to invite the Mayor for lunch at the cooperative's office on the day the cooperative starts the next phase of its expansion plan.

\subsection{The challenge of types of good and types of collective action}

In contrast to other places where community water initiatives were happening, the Bagong Silang community lacked a mature tradition of popular mobilisation, experience of associational democracy and participatory governance. Strong people's organisations do not necessarily have to precede cooperative formation, as the experience of cooperative formation can itself become a space for building community solidarity. However, one lesson is that feasibility planning for a community water cooperative should focus more on the organisational and governance aspects. More than the technical and financial difficulties of setting up community water service associations, it is the shortness of time horizons and the constant search for immediate gains among people who vie for positions of leadership that can lead to failure, and which demands attention. The Maharlika community had been active in the past, both in order to secure the land on which it is located, and in an earlier effort to extend electricity lines. Collective action on such issues is part of its collective history and experience. Nevertheless, it was proving difficult to break with the system of patronage politics, which continues to dominate local politics in the area.

It is worth noting that an element in this specific case was the partnership between the Institute for Popular Democracy and the political party Akbayan. Some local Akbayan activists had been involved in community organising in the rest of Baranggay Bagong Silang, and the director of the IPD is also a member of the party. To Akbayan, the success of the water service cooperative was important for the credibility of their effort in the rest of this giant baranggay; thus, the Akbayan individuals who were active within the water service cooperative initiative were anxious to see the cooperative succeed. Akbayan organisers, who were very active from the point of initiation of the water service cooperative, wanted to present a platform of local community activism that was self-consciously based on self-help, and against patronage. They wanted to harness the approach to draw in the civic energies of people who had until then devoted their energies mainly to individualistic responses to private problems. Because Akbayan did not have access to the resources that feed transactional politics (see Keefer 2005), this small party had the strategic objective of investing in painstaking community organising, and acquiring credibility for what it can accomplish with communities.

Supporting and learning from the co-financing and co-production of community services is very much part of the ongoing work of the IPD; from this learning, it is clear that mixed models are very much the way forward. The Philippines is in the middle of a transition, with both the new widespread decentralisation, popular participation and the Baranggay movement and the old - patronage politics - vying for space. Ostrom's (2002) analysis of the types of goods and collective action points to the notion that bargaining and strategic interaction vary depending on the class or type of initiative being taken up by collective actors. This implies that, while a community's level of social capital, solidarity or organisational capability might be sufficient for some simple challenges, it may be pitifully inadequate for others. Alternatively, existing collective capacities might be uniquely matched to the collective provision of one type of good (e.g. water services), yet may need to be strengthened and draw in specific actors in order to address another (e.g. public health). The challenge for the future is to identify the particular sets of challenges that community organising needs to address in order to tackle the challenges specific to the collective provision of particular kinds of goods and services. 


\section{Note}

1 The Baranggay-Bayan Governance Consortium is a loose network of nongovernment organisations across the Philippines that began engagements with local governments after the People Power revolt and the institutional opportunities provided by decentralisation in 1991 . Members of the Consortium support the empowerment of the poor by utilising different institutional channels opened up by democratisation, by creating community capabilities for increased bargaining power, by supporting local officials who demonstrate a

\section{References}

Hickey, S. and Mohan, G. (2004) (eds) Participation: From Tyranny to Transformation? Exploring New Approaches to Participation in Development, London: Zed Books

Keefer, P. (2005) Democratization and Clientelism: Why are Young Democracies Badly Governed?, World Bank Policy Research Working Paper 3594, Washington DC: World Bank

Lo, Frances (2003) Alimodan Field Reports, Manila, The Philippines: Institute for Popular

Democracy willingness to take risks associated with reform and by working together to identify and change national laws and practices that sustain the exclusionary logic of patronage politics in the country. The result has been an open-ended and collective action research programme that has questioned a number of pre-existing assumptions about participation and local government. In these linked case studies, members of the consortium discuss ongoing experiences of co-production and cofinancing of public services; a step forward from their previous work on participative budgeting.

Ostrom, E. (2002) 'Type of Good and Collective Action', paper presented at the University of Maryland, Collective Choice Center, www.bsos.umd.edu/umccc/ostrom.pdf (accessed 5 August 2009)

Quimpo, N. (2008) Contested Democracy and the Left in the Philippines after Marcos, Manila, The Philippines: Ateneo de Manila University Press 